\title{
Postharvest Quality of Yellow Pear Tomato Cultivated in
}

\section{Aquaponic System}

\author{
João Pedro R. da Silva ${ }^{1}$, Vanderleia Schoeninger ${ }^{1}$, Fabrício C. de Oliveira², Rodrigo A. Jordan ${ }^{1}$, \\ Valdiney C. Siqueira ${ }^{1}$, Elton A. S. Martins ${ }^{1}$, Leonardo O. Seno ${ }^{1}$, Renata H. Hoscher ${ }^{1}$, \\ Wellytton D. Quequeto ${ }^{3} \&$ Geraldo A. Mabasso ${ }^{2}$ \\ ${ }^{1}$ Faculty of Agrarian Sciences, Federal University of Grande Dourados, Dourados, Brazil \\ ${ }^{2}$ Federal University of Technology, Paraná, Santa Helena Brazil \\ ${ }^{3}$ Federal Institute of Education, Science and Technology Goiano, Rio Verde, Brazil \\ Correspondence: Fabrício C. de Oliveira, Federal University of Technology, Paraná, Santa Helena, Paraná, \\ Brazil. Tel: 55-453-268-8818. E-mail: fcoliveira@utfpr.edu.br
}

Received: June 3, $2019 \quad$ Accepted: July 13, $2019 \quad$ Online Published: September 15, 2019

doi:10.5539/jas.v11n15p227 URL: https://doi.org/10.5539/jas.v11n15p227

\begin{abstract}
The production of vegetables in aquaponic systems has high sustainability and conservation of natural resources, but studies that make their cultivation feasible under Brazilian conditions are still incipient. Given the influence that the cultivation system can cause on the postharvest characteristics of fruits and vegetables, this study aimed to evaluate the postharvest quality of yellow pear tomato cultivated in an aquaponic system. Tomato plants were grown in a protected environment, in the experimental area of aquaponics of the Faculty of Agrarian Sciences, belonging to the Federal University of Grande Dourados. The experimental design was completely randomized in a factorial scheme, with two factors: maturity stage at harvest and storage time. Three stages of fruit maturity (green, intermediate and ripe) and two storage times (zero and 35 days) were analyzed. Tomato samples were subjected to the analyses using the whole fruit, evaluated for mass loss, color and firmness, and the fruit pulp, evaluated for soluble solids (SS), titratable acidity (TA), SS/TA ratio, $\mathrm{pH}$ and lycopene content. The fruits of yellow pear tomato cultivated in aquaponic system were in satisfactory conditions with respect to the postharvest parameters evaluated, indicating great potential to be cultivated on a commercial scale under Brazilian conditions. The parameters analyzed were similar or superior to the parameters of tomatoes grown in other cropping systems.
\end{abstract}

Keywords: maturity stages, mass loss, Solanum lycopersicum, storage time

\section{Introduction}

The aquaponic system can be defined as a set of technologies that integrate the plant cultivation with fish farming in a symbiotic production system. Fish farming wastes are used as fertilizers for plant production and plants contribute to the removal of metabolic substances, which may be harmful to fish development, acting in the conditioning of water quality for fish farming (Goddek et al., 2016; Hundley et al., 2013; Roosta \& Afsharipoor, 2012).

Vegetable cultivation in aquaponic system is a very widespread technique in several countries of the world, but in Brazil there are no reports about aquaponic cultivation on a commercial scale. However, studies have been conducted in an attempt to provide information that contributes to the implementation of this cultivation technique (Geisenhoff, Jordan, Santos, Oliveira, \& Gomes, 2016; Jordan, Ribeiro, Oliveira, Geisenhoff, \& Martins, 2018).

In order to contribute with the required information to the implementation of the aquaponic system, on a commercial scale, under Brazilian conditions, it is necessary to conduct studies on the postharvest quality of the vegetables produced in aquaponic system, since the cultivation system and postharvest handling conditions can directly influence the qualitative parameters of the fruits, especially the climacteric ones, such as tomato (Ceglie, Amodio, \& Colelli, 2016; Khadka, Marasini, Rawal, Gautam, \& Acedo, 2017; Rocha, Ribeiro, \& Silva, 2018).

Tomato is a perishable fruit and, during the postharvest period, its qualitative and nutritional characteristics are susceptible to major alterations. Harvested fruits are subject to mass reduction (Oliveira, Coneglian, \& Carmo, 2015), alterations of color (Andreuccetti, Ferreira, Moretti, \& Honório, 2007), alterations in physical and chemical 
composition (Ferreira et al., 2010), among others. Given the influence that the cultivation system can cause on the postharvest characteristics of tomato, this study aimed to evaluate the postharvest quality of yellow pear tomato cultivated in aquaponic system.

\section{Material and Methods}

Tomato plants were grown in a protected environment, in the experimental area of aquaponics of the Faculty of Agrarian Sciences (FCA), belonging to the Federal University of Grande Dourados (UFGD), located in Dourados, Mato Grosso do Sul, Brazil ( $22^{\circ} 11^{\prime} 45^{\prime \prime} \mathrm{S}, 54^{\circ} 55^{\prime} 8^{\prime \prime} \mathrm{W}$ and $446 \mathrm{~m}$ of altitude).

The aquaponic system used consisted of six fish-farming tanks connected in series with a plant bed. Fish farming wastewater was treated by means of decanters and biological filters. The nutrient solution used for plant cultivation consisted of a mixture of wastewater (liquid fraction from the decanter) and biofertilizer (solid fraction from the decanter) in a volumetric proportion of 100:6. Fish population density was $100 \mathrm{fish}^{-3}$. The fish species used was tilapia (Oreochromis niloticus), GIFT strain. Details on the conduction of the aquaponic system can be seen in the works of Geisenhoff, Jordan, Santos, Oliveira, and Gomes (2016) and Jordan, Ribeiro, Oliveira, Geisenhoff, and Martins (2018).

Yellow pear tomato plants were cultivated on a floating raft, which was $12 \mathrm{~m}$ long and $1.2 \mathrm{~m}$ wide, at density of 6 plants $\mathrm{m}^{-2}$.

The experimental design was completely randomized in a factorial scheme, with two factors: maturity stage at harvest and storage time. Three maturity stages (green, intermediate and ripe) and two storage times (zero and 35 days) were analyzed. Normality (Shapiro-Wilk test) and equality of variances (Levene's test) were analyzed at 5\% significance level. For data that did not meet the assumptions of normality and equality of variance, Box-Cox transformation was used. Subsequently, the analysis of variance was carried out with $F$ test $(p \leq 0.05)$. Data of mass loss and color were evaluated using descriptive analysis, presenting the mean values obtained with their respective standard deviations. In addition, when significant, regression analysis relating the response variable as a function of the variation in storage time was performed.

After harvest, the fruits were properly sanitized with running water and dried with paper towels in the Laboratory of Physical Properties of Agricultural Products of UFGD. The tomatoes were classified into three maturity stages, according to their color in three groups: green (Stage I), intermediate (Stage II) and ripe (Stage III) (Figure 1).

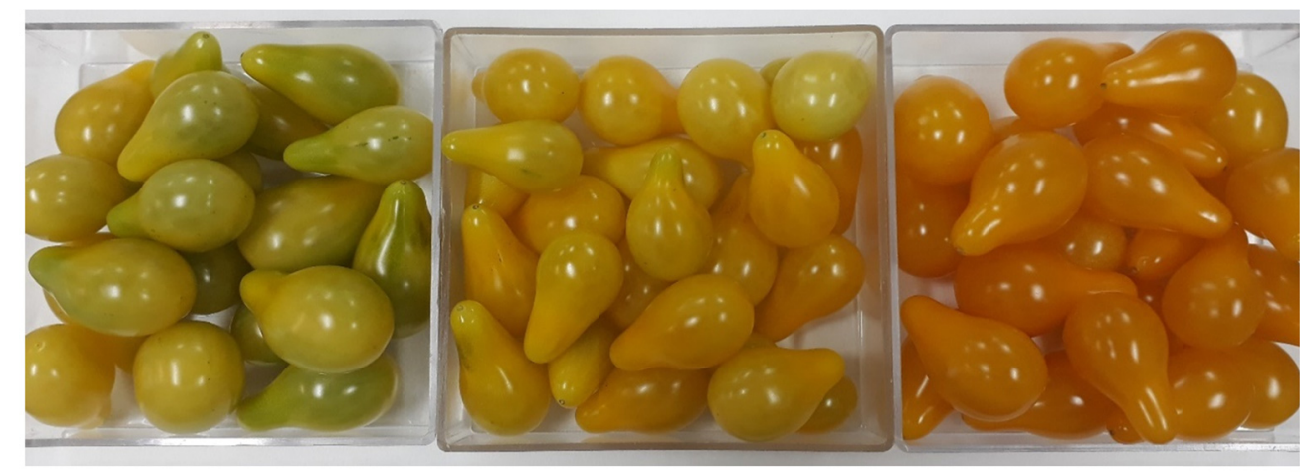

Stage I

Stage II

Stage III

Figure 1. Classification of yellow pear tomato fruits produced in an aquaponic system and harvested at three maturity stages

Subsequently, samples of approximately $50 \mathrm{~g}$ were taken and placed in polyethylene terephthalate (PET) plastic packages. These samples were subjected to ambient storage conditions, simulating the shelf conditions found in the retail market.

Fruit storage began on May 24, 2017 and ended on June 26, 2017. The average air temperature ranged from 18.5 to $27.3^{\circ} \mathrm{C}$ and the relative humidity ranged from 48.7 to $91.7 \%$ (Figure 2 ). 


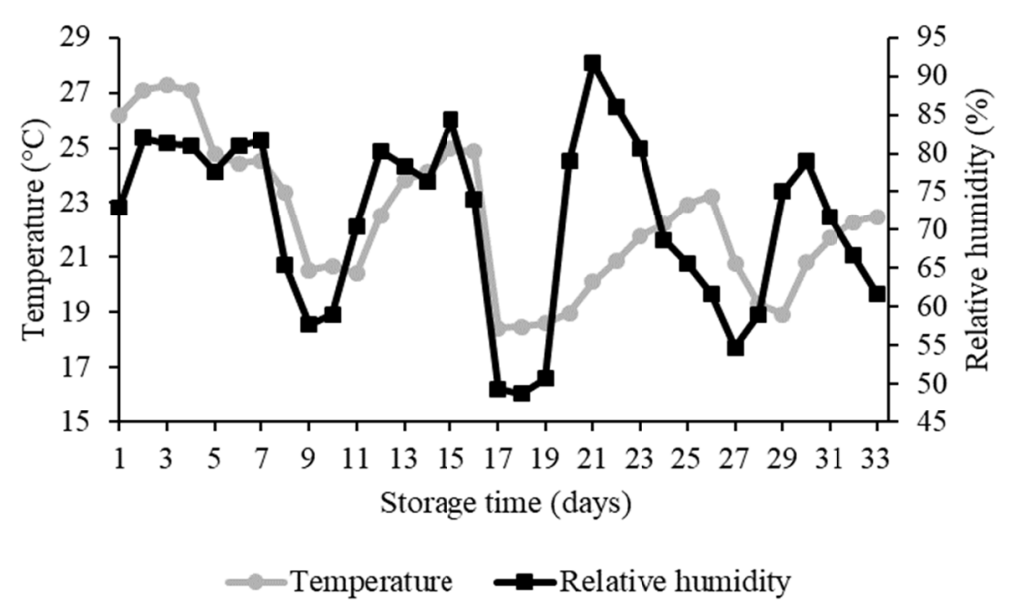

Figure 2. Average values of air temperature $\left({ }^{\circ} \mathrm{C}\right)$ and relative humidity $(\%)$ during the period of storage of yellow pear tomato fruits

Tomato samples were subjected to analyses using the whole fruit, evaluated for mass loss, color and firmness, and fruit pulp, evaluated for the content of soluble solids (SS), titratable acidity (TA), SS/TA ratio, pH and lycopene content.

\subsection{Quality Analyses Using Whole Fruit}

The loss of fresh mass (\%) was determined based on the initial and final masses obtained daily in the measurements. Fruit color was determined by direct reading in colorimeter (Konica Minolta CR400 with CIELAB color space and illuminant D65), expressing the color variables $\mathrm{L}^{*}, \mathrm{a}^{*}$ and $\mathrm{b}^{*}$, which correspond to the values of lightness, green-red and blue-yellow, respectively. The parameters hue angle $\left(\mathrm{H}^{*}\right)$ and chroma $\left(\mathrm{C}^{*}\right)$ of the fruits were determined according to Equations 1 and 2, respectively.

$$
\mathrm{H}^{*}=\tan ^{-1}\left(\frac{\mathrm{b}^{*}}{\mathrm{a}^{*}}\right)
$$

Where, $\mathrm{H}^{*}=$ hue angle or chromatic tone (degrees); $\mathrm{a}^{*}=$ red-green color component; and, $\mathrm{b}^{*}=$ yellow-blue color component.

$$
\mathrm{C}^{*}=\sqrt{\left(\mathrm{a}^{*}\right)^{2}+\left(\mathrm{b}^{*}\right)^{2}}
$$

Where, $\mathrm{C}^{*}=$ chroma (dimensionless); $\mathrm{a}^{*}=$ red-green color component; and, $\mathrm{b}^{*}=$ yellow-blue color component.

Firmness of tomato fruits was evaluated with a Texture Analyzer (TA-HDi $25 \mathrm{~kg}$ ), individually measured in each fruit. The parameters for this analysis were pre-test, test and post-test speeds of $1.00 \mathrm{~mm} \mathrm{~s}^{-1}, 2.00 \mathrm{~mm} \mathrm{~s}^{-1}$ and 5.00 $\mathrm{mm} \mathrm{s}^{-1}$, respectively. Probe penetration distance was determined based on the average fruit diameter $(30 \mathrm{~mm})$, measured with a digital caliper, being equal to $6 \mathrm{~mm}$ or $20 \%$ of this value. The probe used had diameter of $45 \mathrm{~mm}$ according to the device's manual and is indicated for grapefruits, whose shape is the closest one to that of a yellow pear tomato.

\subsection{Quality Analyses Using Fruit Pulp}

Initially, the concentrated pulp of the fruits was obtained using a mixer homogenizer. After that, direct readings of soluble solids (SS), expressed in ${ }^{\circ}$ Brix, were taken in a small sample of the pulp using a digital refractometer $\left(\right.$ MEGABRIX $\left.^{\circledR}\right)($ AOAC, 2000).

Titratable acidity (TA) was obtained by volumetric titration method with indicator. $5 \mathrm{~g}$ of pulp were placed in a 125 -mL Erlenmeyer flask, which received 2 drops of $1 \%$ alcoholic phenolphthalein. The pulp was titrated up to the turning point $(\mathrm{pH}=8.2)$, under agitation, with a $1.0 \mathrm{~mol} \mathrm{~L}^{-1} \mathrm{NaOH}$ solution. The results correspond to the relationship between grams of $\mathrm{NaOH}$ solution per $100 \mathrm{~g}$ of pulp $\left(\mathrm{g} \mathrm{NaOH} 100 \mathrm{~g}^{-1}\right)$, expressed as \% (AOAC, 2000)

Then, the SS/TA ratio was calculated as the ratio between the values of SS and TA. In addition, $\mathrm{pH}$ readings were also performed, using a portable digital $\mathrm{pH}$ meter. These readings were taken directly in the fruit pulp.

Lycopene concentration in fruits was determined by spectrophotometric analysis, using 5-g pulp samples. Each sample received $40 \mathrm{~mL}$ of acetone. The mixture was stirred for $1 \mathrm{~h}$ using an orbital shaker table at $200 \mathrm{rpm}$ and filtered using filter paper, and $20 \mathrm{~mL}$ of acetone were added again to the filtrate for extraction. $40 \mathrm{~mL}$ of petroleum 
ether and distilled water, together with a separation funnel, were placed in the $80 \mathrm{~mL}$ of solution obtained after extractions. The lower part of the filter was discarded because it contained only acetone with distilled water. The upper part of the funnel contained the ether with pigment, which were transferred to a $50-\mathrm{mL}$ volumetric flask. The reading in a spectrophotometer (Micronal B495) was taken at $470 \mathrm{~nm}$ wavelength. Lycopene content was obtained according to Equation 3.

$$
\mu \mathrm{g} / \mathrm{g}=\frac{\mathrm{AV} 1.000 .000}{\mathrm{~A}_{\mathrm{lcm}}^{10} \mathrm{M} 100}
$$

Where, $\mu \mathrm{g} / \mathrm{g}=$ lycopene content $\left(\mu \mathrm{g} \mathrm{g}^{-1}\right) ; \mathrm{A}=$ absorbance of the solution at $470 \mathrm{~nm}$ wavelength; $\mathrm{V}=$ final volume of the solution; $A_{1 \mathrm{~cm}}^{1 \%}=$ is the extinction coefficient or molar absorptivity coefficient of a pigment in a specific solvent, equal to 3450 for lycopene in petroleum ether; and, $\mathrm{M}=$ mass of the sample taken for analysis (g).

\section{Results and Discussion}

Regarding the loss of fresh mass, LFM (\%), all maturity stages showed the same trend, increase of LFM as a function of the evaluation time. Stage III, after 35 days of storage, showed a higher mean reduction (3.25\%), but the LFM values for the stages II and I were similar (2.96 and 3.12\%, respectively) (Figure 3A).
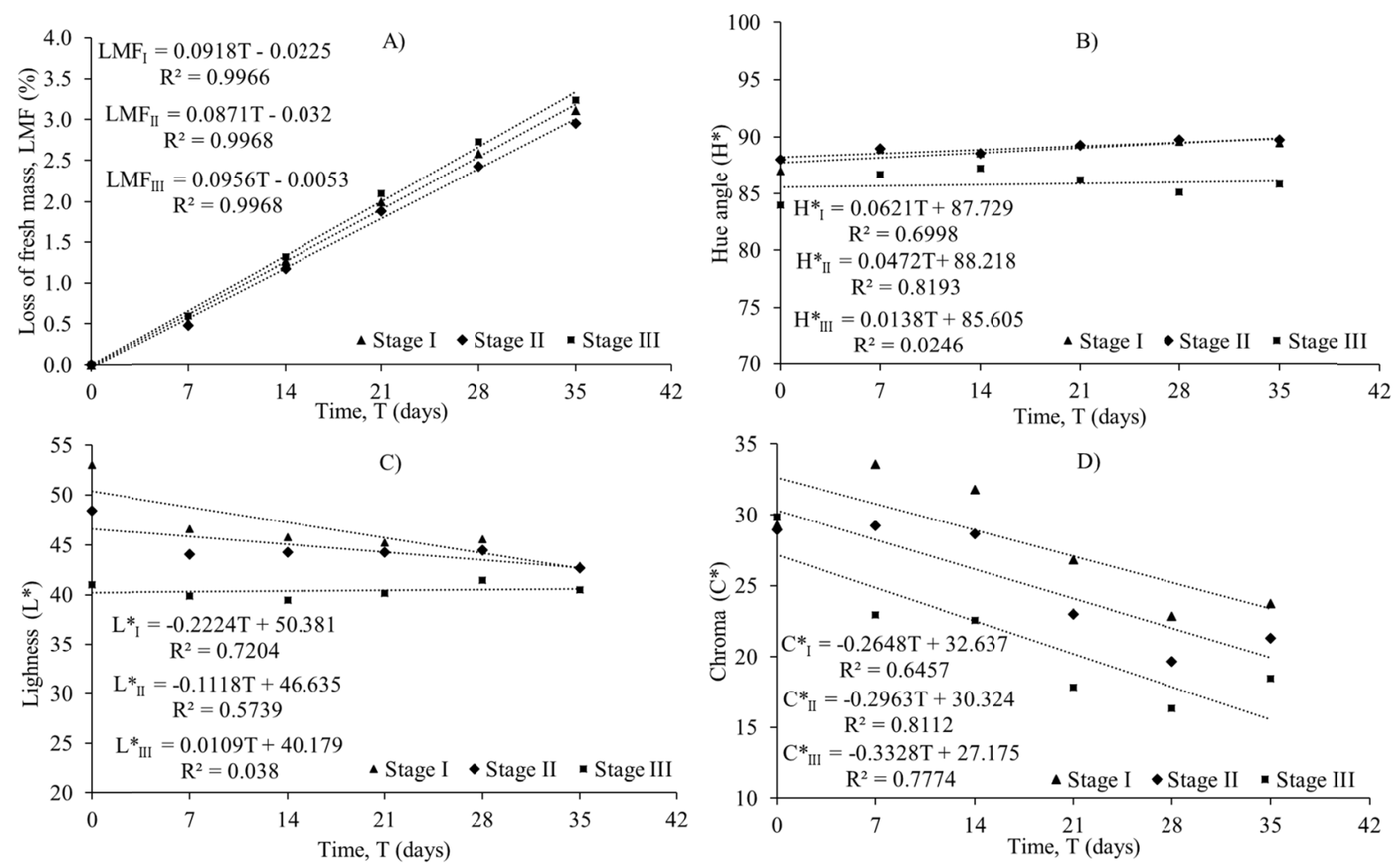

Figure 3. Loss of fresh mass, LFM (\%)—(A); Hue angle $\left(\mathrm{H}^{*}\right)-(\mathrm{B})$; Lightness $\left(\mathrm{L}^{*}\right)-(\mathrm{C})$; and Chroma $\left(\mathrm{C}^{*}\right)$ - (D) of yellow pear tomato fruits harvested at three maturity stages and stored under ambient conditions for 35 days

Regardless of the stage at which the fruits were harvested, it was observed that LFM was small in comparison to the storage time. Studies report higher losses than those found in the present study, such as Oliveira, Coneglian, and Carmo (2015), who evaluated the postharvest conservation of cherry tomatoes and observed LFM of $7 \%$ at 24 days of storage, and Modolon, Boff, Rosa, Sousa, and Miquelluti (2012), who analyzed the postharvest quality of tomatoes and observed LFM of $6 \%$ at 14 days of storage. In the present study, at 24 and 14 days of evaluation, considering maturity stage III, the LFM values were 2.29 and $1.33 \%$, respectively. Thus, it is observed that the fruits had lower LFM compared to those reported in the literature.

Regarding the visual aspect, after 35 days of storage, under ambient conditions, the fruits remained with the characteristics desired by the consumer, with good visual appearance, firm and with no damage caused by microorganisms (Figure 4). Thus, it indicates the potential of this fruit with respect to maintaining its quality in the postharvest phase. 


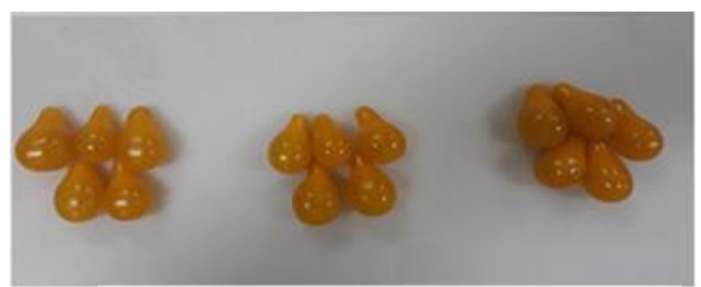

\section{Stage I Stage II Stage III}

Figure 4. Visual appearance of yellow pear tomato fruits harvested at three maturity stages after 35 days of storage under ambient conditions

In relation to the color angle $\left(\mathrm{H}^{*}\right)$, the variation of $\mathrm{H}^{*}$ was higher in the first evaluation (zero storage time), demonstrating the predominance of the component $\mathrm{a}^{*}$ with negative values (greener and less red) and $\mathrm{b}^{*}$ with positive values (more yellow and less blue) (Figure 3B).

From the seven days of storage, the difference between the $\mathrm{H}^{*}$ values decreases. All tomatoes began to show color coordinates positioned in the quadrant of positive values $\mathrm{a}^{*}$ and $\mathrm{b}^{*}$, i.e., predominance of yellow in the color composition. Cherry tomato maturity can be analyzed based on color (Pereira, León, Hernández, \& Gonzáçez, 2012).

In general, maturation begins with fruits showing shades of green, changing to reddish and completing their maturation with yellowish color, as reported in the present study.

The coordinate $\mathrm{L}^{*}$ in the CIELAB color space varies from 0 (absolute black) to 100 (absolute white). The tomatoes harvested at stages I and II showed a tendency to darkening as a function of the storage time. Tomatoes harvested at stage III maintained lightness, but were darker than tomatoes harvested at the other stages (Figure 3C).

During maturation, tomato fruits have a high synthesis of carotenoids, associated with color changes. Initially, the synthesis of the phytoene (colorless) occurs. Subsequently, the $\zeta$-carotene (dull yellow), lycopene (red), $\beta$-carotene (orange), xanthophylls and hydroxyl carotenoids (yellow) are synthesized (Pereira et al., 2012).

Reduction in the parameter lightness as a function of storage time was also observed by Camelo \& Gómez (2004). L* values, at stages I and II, indicate that the fruits were harvested before the beginning of the synthesis of red and orange pigments (lycopene). At stage III, the synthesis was already complete, so the color was maintained during the 35 days of storage.

Chroma distinguishes a strong color from a weak color, expressing the intensity of the perception of fruit color. Fruits harvested at stage I had higher values of chroma, indicating greater perception of color. The values of the component $\mathrm{a}^{*}$, as a function of time, changed from more positive values (green) to more negative values (red) (Figure 3D).

Tomatoes harvested at stages I, II and III, after 35 days of storage under ambient conditions, showed chroma reductions of 23, 40 and $61 \%$, respectively. Thus, tomatoes harvested at stage I maintained their color intensity for longer, tending to remain yellow. Reduction of chroma as a function of storage time in cherry tomato cultivation was also observed by Pereira, León, Hernández, and Gonzáçez (2012).

This parameter can be used to assist in the selection of the best stage for fruit harvesting, especially in this case, in which there is a lack of information for aquaponic cultivation under national conditions (Jordan, Geisenhoff, Oliveira, Santos, \& Martins, 2018).

In relation to the contents of soluble solids, $\mathrm{SS}\left({ }^{\circ} \mathrm{Brix}\right)$, there were significant effects of maturity stage (Figure $5 \mathrm{~A})$ and storage time (Figure 5B), with no interaction between them $(\mathrm{p} \leq 0.05)$. Tomatoes harvested at stage III had higher values SS ( $4.73^{\circ}$ Brix) compared to those harvested at stage I ( $4.38^{\circ}$ Brix $)$. 

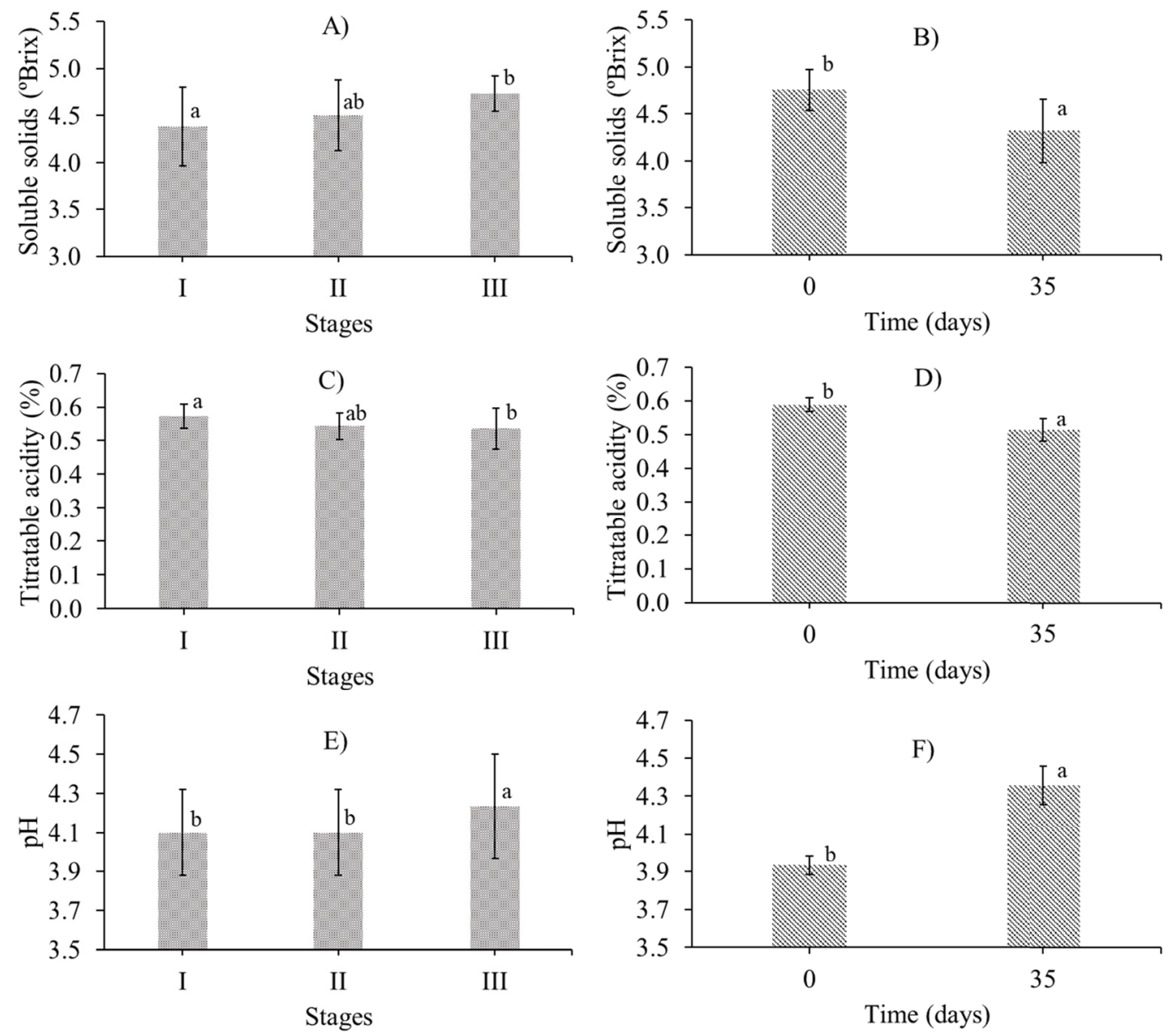

Figure 5. Mean values of soluble solids, SS ( ${ }^{\circ}$ Brix); titratable acidity, TA (\%); and, $\mathrm{pH}$ of yellow pear tomato fruits as a function of three maturity stages at harvest and as a function of storage time under ambient conditions

Regarding storage time, there was a reduction in SS content. After 35 days of natural storage, the fruits had a 10\% reduction in the SS content, from $4.76^{\circ} \mathrm{Brix}$ at the beginning of the storage period to $4.32{ }^{\circ} \mathrm{Brix}$ at the end of the period.

Similar results were observed by Modolon et al. (2012), analyzing the postharvest quality of tomato fruits subjected to different dilutions, with mean value of $4.11^{\circ}$ Brix. The contents of soluble solids are related to the flavor of tomato fruits and, as observed in the results, the values presented in this study were similar to those obtained in tomatoes cultivated in conventional systems, demonstrating the possibility of production in an aquaponic system with no depreciation in fruit flavor.

For the parameter titratable acidity (TA), there were significant effects of maturity stage (Figure 5C) and storage time (Figure 5D), with no interaction between them $(\mathrm{p} \leq 0.05)$. There was a reduction of $6.8 \%$ in TA when the maturity stage I is compared to the stage III. TA also decreased as a function of storage time, from $0.58 \%$, at the beginning of the evaluations, to $0.51 \%$, after 35 days of storage under ambient conditions. Similar results were observed by Ferreira et al. (2010), evaluating the postharvest quality of table tomato in two cropping systems, conventional and organic. These authors observed reductions in titratable acidity around $0.20 \%$ for tomatoes from conventional cultivation and $0.21 \%$ for tomatoes from organic cultivation.

Reduction of TA may result from respiratory processes and/or conversion of organic acids into sugars (Ferreira et al., 2010; Wills \& Ku, 2002).

Thus, it can be observed that the tomatoes from the aquaponic cultivation, even at maturity stage I, have higher contents of organic sugars compared to the contents observed in organic and conventional crops.

The factors maturity stage (Figure 5E) and storage time (Figure 5F) had significant effect on tomato pulp pH, with no interaction between them $(\mathrm{p} \leq 0.05)$. 
Values of $\mathrm{pH}$ in tomato fruits may vary according to the cultivation system; however, in general, acidic $\mathrm{pH}$ values are desirable, since they reduce the proliferation of microorganisms, which can increase fruit longevity (Modolon et al., 2012; Ramos et al., 2013). In the present study, $\mathrm{pH}$ values ranged from 4.1 to 4.2 (in relation to the maturity stage) and 3.9 to 4.3 (in relation to storage time). Thus, with respect to the parameter $\mathrm{pH}$, tomatoes from aquaponic cultivation also have potential to be marketed in a similar way to fruits from other cultivation systems.

For the SS/TA ratio, there was significant effect of maturity stage and not significant effect of storage time. The interaction between these factors was significant $(\mathrm{p} \leq 0.05)$. Table 1 shows the mean values of SS/TA ratio, lycopene content and firmness of yellow pear tomato fruits as a function of three maturity stages and of storage time under ambient conditions.

Table 1. Mean values for SS/TA ratio, lycopene content and firmness of yellow pear tomato fruits as a function of three maturity stages at harvest and of storage time under ambient conditions

\begin{tabular}{|c|c|c|c|}
\hline \multirow{2}{*}{ Stage } & \multicolumn{2}{|c|}{ Time (days) } & \multirow{2}{*}{ Mean } \\
\hline & 0 & 35 & \\
\hline \multicolumn{4}{|c|}{ SS/TA ratio } \\
\hline I & $7.84 \pm 0.13^{\mathrm{aA}}$ & $7.42 \pm 0.29^{\mathrm{bA}}$ & 7.63 \\
\hline II & $8.35 \pm 0.33^{\mathrm{aB}}$ & $8.43 \pm 0.53^{\mathrm{aA}}$ & 8.39 \\
\hline III & $8.05 \pm 0.25^{\mathrm{aB}}$ & $9.55 \pm 0.69^{\mathrm{aA}}$ & 8.80 \\
\hline Mean & 8.08 & 8.47 & - \\
\hline \multicolumn{4}{|c|}{ Lycopene content $\left(\mu g g^{-1}\right)$} \\
\hline I & $13.68 \pm 0.00^{\mathrm{cA}}$ & $14.13 \pm 0.25^{\mathrm{cA}}$ & 13.903 \\
\hline II & $11.36 \pm 0.00^{\mathrm{bB}}$ & $14.72 \pm 0.41^{\mathrm{bA}}$ & 13.042 \\
\hline III & $14.88 \pm 0.00^{\mathrm{aB}}$ & $17.14 \pm 0.16^{\mathrm{aA}}$ & 16.002 \\
\hline Mean & 13.303 & 15.328 & - \\
\hline \multicolumn{4}{|c|}{ Firmness (N) } \\
\hline I & $22.46 \pm 1.26^{\mathrm{aA}}$ & $17.94 \pm 1.27^{\mathrm{aB}}$ & 20.204 \\
\hline II & $18.92 \pm 1.79^{\mathrm{bA}}$ & $16.26 \pm 0.62^{\mathrm{aA}}$ & 17.592 \\
\hline III & $16.70 \pm 0.37^{\mathrm{bA}}$ & $16.61 \pm 1.50^{\mathrm{aA}}$ & 16.657 \\
\hline Mean & 19.364 & 16.938 & - \\
\hline
\end{tabular}

Note. Mean value \pm standard deviation. Equal letters, uppercase in the row and lowercase in the column, correspond to equal means by Tukey test at $5 \%$ significance level.

The SS/TA ratio is responsible for the characteristic flavor of the fruits, and high values of this ratio indicate an optimal combination of sugars and acids that are correlated with the soft flavor of the fruits (Ramos et al., 2013). It is observed that tomatoes harvested at stages II and III showed significant increment after 35 days of storage under ambient conditions, with the highest increment obtained at the maturity stage III (18.6\%).

Lycopene content was influenced by the factors maturity stage, storage time and the interaction between them (p $\leq 0.05$ ). Lycopene contents increased as a function of storage time and maturity stage. The highest value observed was $17.14 \mu \mathrm{g} \mathrm{g}^{-1}$, after 35 days of storage, in fruits at maturity stage III. The lowest lycopene content was observed at the beginning of the storage period, in fruits at maturity stage II (Table 1).

The unique chemical structure of lycopene confers a remarkable antioxidant action, contributing to the prevention of degenerative diseases, cardiovascular diseases and certain types of cancer. In addition, it gives desirable appearance to the fruits, since it increases their dark reddish pigmentation. Thus, high lycopene contents in the fruits are desirable, both for fresh commercialization and for industrial processing (Carvalho, Fonseca, Silva, Boiteux, \& Giordano, 2005; Marodin et al., 2016). The contents obtained in the present study were satisfactory, even at the initial maturity stages. The values obtained for lycopene content demonstrate the potential of yellow pear tomato production in aquaponic systems.

For the parameter fruit firmness, there was a significant effect of the factors maturity stage, storage time and the interaction between them $(\mathrm{p} \leq 0.05)$. Fruit firmness decreased as a function of storage time and maturity stage. 
The condition with highest firmness was observed on the first day of storage, in fruits at stage I $(22.46 \pm 1.26 \mathrm{~N})$ (Table 1).

The results observed in the present study were higher than those reported by Bernardi et al. (2007), evaluating the production and quality of tomato fruits grown in a substrate with zeolite. These authors found values of firmness varying from 7.06 to $14.38 \mathrm{~N}$. Marodin et al. (2016) analyzed the postharvest characteristics of tomato as a function of doses of silicate fertilizers and obtained firmness values from 9.5 to $10.6 \mathrm{~N}$. Softening or loss of firmness in the pulp results from the solubilization of pectic substances from the cell wall through the action of pectin methylesterase (PME) and polygalacturonase (PG), whose activities are increased at the beginning of ripening and in the senescence, especially PG, which peaks at the ripe stage (Ferreira et al., 2010).

Firmness is an important attribute in the postharvest evaluations of tomato fruits, since it is related to the maintenance of other qualitative parameters during their transport and commercialization (Bernardi et al., 2007). Thus, it can be observed that fruits from the aquaponic production showed satisfactory results. These results can be attributed to the adequate nutrition provided for plants during their development, so that, in general, the higher the fertilizer dose added during plant development, the greater firmness of tomato fruits, especially fertilizers with high levels of phosphorus and silicates (Bernardi et al., 2007; Marodin et al., 2016).

\section{Conclusions}

This reserch aimed to contribuite with information that may enable the aquaponic production of yellow pear tomatoes in commercial scale in Brazil. For this, the post-harvest quality of fruits from the aquaponic system production was evaluated. It was observed that fruits grown in aquaponic system maintained their postharvest quality, based on the parameters evaluated, indicating great potential to be cultivated on a commercial scale under Brazilian conditions. After 35 days under ambient conditions, tomatoes harvested at different maturity stages maintained satisfactory physicochemical characteristics. The parameters analyzed were similar or superior to the parameters of tomatoes grown in other cropping systems. These results provide information to increase the technique of aquaponic production in Brazil.

\section{References}

Andreuccetti, C., Ferreira, M. D., Moretti, C. L., \& Honório, S. L. (2007). Qualidade Pós-Colheita De Tomates 'Débora' Tratados Com Etileno. Revista Brasileira de Engenharia de Biossistemas, 1(3), 245. https://doi.org/10.18011/bioeng2007v1n3p245-253

AOAC. (2000). Official Methods of Analysis of the Association of Official Analytical Chemists. AOAC International. Retrieved from https://books.google.com.br/books/about/Official_Methods_of_Analysis _of_the_Asso.html?id=TDAbAQAAMAAJ\&redir_esc $=\mathrm{y}$

Bernardi, A. C. de C., Werneck, C. G., Haim, P. G., Botrel, N., Oiano-Neto, J., Monte, M. B. de M., \& Verruma-Bernardi, M. R. (2007). Produção e qualidade de frutos de tomateiro cultivado em substrato com zeólita. Horticultura Brasileira, 25(2), 306-311. https://doi.org/10.1590/S0102-05362007000200035

Camelo, A. F. L., \& Gómez, P. A. (2004). Comparison of color indexes for tomato ripening. Horticultura Brasileira, 22(3), 534-537. https://doi.org/10.1590/S0102-05362004000300006

Carvalho, W., Fonseca, M. E., Silva, H. ., Boiteux, L., \& Giordano, L. (2005). Estimativa indireta de teores de licopeno em frutos de genótipos de tomateiro via análise colorimétrica. Horticultura Brasileira, 232(3), 819-825. https://doi.org/10.1590/S0102-05362005000300026

Ceglie, F., Amodio, M., \& Colelli, G. (2016). Effect of Organic Production Systems on Quality and Postharvest Performance of Horticultural Produce. Horticulturae, 2(2), 4. https://doi.org/10.3390/horticulturae2020004

Ferreira, S. M. R., Quadros, D. A. de, Karkle, E. N. L., Lima, J. J. de, Tullio, L. T., \& Freitas, R. J. S. de. (2010). Qualidade pós-colheita do tomate de mesa convencional e orgânico. Ciência e Tecnologia de Alimentos, 30(4), 858-869. https://doi.org/10.1590/S0101-20612010000400004

Geisenhoff, L. O., Jordan, R. A., Santos, R. C., Oliveira, F. C., \& Gomes, E. P. (2016). Effect of different substrates in aquaponic lettuce production associated with intensive tilapia farming with water recirculation systems. Engenharia Agrícola, 36(2), 291-299. https://doi.org/10.1590/1809-4430-Eng.Agric.v36n2 p291-299/2016

Goddek, S., Espinal, C., Delaide, B., Jijakli, M., Schmautz, Z., Wuertz, S., \& Keesman, K. (2016). Navigating towards Decoupled Aquaponic Systems: A System Dynamics Design Approach. Water, 8(7), 303. https://doi.org/10.3390/w8070303 
Hundley, G. M. C., Navarro, R. D., Figueiredo, C. M. G., Navarro, F. K. S. P., Pereira, M. M., Filho, O. P. R., \& Filho, J. T. S. (2013). Aproveitamento do efluente da produção de tilápia do nilo para o crescimento de manjericão (Origanum basilicum) e manjerona (Origanum majorana) em sistemas de aquaponia. Revista Brasileira de Agropecuária Sustentável, 3(1).

Jordan, R. A., Geisenhoff, L. O., Oliveira, F. C., Santos, R. C., \& Martins, E. A. S. (2018). Yield of lettuce grown in aquaponic system using different substrates. Revista Brasileira de Engenharia Agrícola e Ambiental, 22(1), 27-31. https://doi.org/10.1590/1807-1929/agriambi.v22n1p27-31

Jordan, R. A., Ribeiro, E. F., Oliveira, F. C. de, Geisenhoff, L. O., \& Martins, E. A. S. (2018). Yield of lettuce grown in hydroponic and aquaponic systems using different substrates. Revista Brasileira de Engenharia Agrícola e Ambiental, 22(8), 525-529. https://doi.org/10.1590/1807-1929/agriambi.v22n8p525-529

Khadka, R. B., Marasini, M., Rawal, R., Gautam, D. M., \& Acedo, A. L. (2017). Effects of Variety and Postharvest Handling Practices on Microbial Population at Different Stages of the Value Chain of Fresh Tomato (Solanum lycopersicum) in Western Terai of Nepal. BioMed Research International, 1-6. https://doi.org/10.1155/2017/7148076

Marodin, J. C., Resende, J. T. V, Morales, R. G. F., Faria, M. V, Trevisam, A. R., Figueiredo, A. S. T., \& Dias, D. M. (2016). Tomato post-harvest durability and physicochemical quality depending on silicon sources and doses. Horticultura Brasileira, 34(3), 361-366. https://doi.org/10.1590/S0102-05362016003009

Modolon, T. A., Boff, P., Rosa, J. M. da, Sousa, P. M. R. de, \& Miquelluti, D. J. (2012). Qualidade pós-colheita de frutos de tomateiro submetidos a preparados em altas diluições. Horticultura Brasileira, 30(1), 58-63. https://doi.org/10.1590/S0102-05362012000100010

Oliveira, C. M., Coneglian, R. C. C., \& Carmo, M. G. F. (2015). Conservação pós-colheita de tomate cereja revestidos com película de fécula de mandioca. Horticultura Brasileira, 33(2), 251-256. https://doi.org/ $10.1590 / \mathrm{S} 0102-053620150000400011$

Pereira, C. A. P., León, G. M. P., Hernández, A. I. M., \& Gonzáçez, R. A. O. (2012). Determinación del color en epicarpio de tomates (Lycopersicum esculentum Mill.) con sistema de visión computarizada durante la maduración. Agronomía Costarricense, 36(1), 97-111.

Ramos, A. R. P., Amaro, A. C. E., Macedo, A. C., De Assis Sugawara, G. S., Evangelista, R. M., Rodrigues, J. D., \& Ono, E. O. (2013). Qualidade de frutos de tomate 'giuliana' tratados com produtos de efeitos fisiológicos. Semina: Ciencias Agrarias, 34(6, SP1), 3543-3552. https://doi.org/10.5433/1679-0359.2013 v34n6Sup11p3543

Rocha, R. G. L., Ribeiro, M. C. C., \& Silva, F. D. B. (2018). Maturação físiológica e armazenamento pós-colheita de frutos e sementes de tomate cereja em transição agroecológica. Agropecuária Científica No Semiárido, 14(1), 36-41. https://doi.org/10.30969/acsa.v14i1.926

Roosta, H. R., \& Afsharipoor, S. (2012). Effects of different cultivation media on vegetative growth, ecophysiological traits and nutrients concentration in strawberry under hydroponic and aquaponic cultivation systems. Advances in Environmental Biology, 6(2), 543-555.

Wills, R. B. H., \& Ku, V. V. V. (2002). Use of 1-MCP to extend the time to ripen of green tomatoes and postharvest life of ripe tomatoes. Postharvest Biology and Technology, 26(1), 85-90. https://doi.org/10.1016/ S0925-5214(01)00201-0

\section{Copyrights}

Copyright for this article is retained by the author(s), with first publication rights granted to the journal.

This is an open-access article distributed under the terms and conditions of the Creative Commons Attribution license (http://creativecommons.org/licenses/by/4.0/). 